Article

\title{
Premature Apple Fruit Drop: Associated Fungal Species and Attempted Management Solutions
}

\author{
Khamis Youssef $1, *(1)$ and Sergio Ruffo Roberto ${ }^{2, *(1)}$ \\ 1 Agricultural Research Center, Plant Pathology Research Institute, 9 Gamaa St., Giza 12619, Egypt \\ 2 Agricultural Research Center, Department of Agronomy, Londrina State \\ University, Londrina 86057-970, PR, Brazil \\ * Correspondence: youssefeladawy@yahoo.com (K.Y.); sroberto@uel.br (S.R.R.)
}

Received: 18 March 2020; Accepted: 22 May 2020; Published: 26 May 2020

\begin{abstract}
The aim of this research was to determine the incidence and possible causal pathogen(s) of premature apple fruit drop (PAFD), and also to assess some fungicides for controlling the disease organisms, in order to promote a sustainable system in orchards. The prevalence and natural incidence of apple fruit drop in cv. Anna was assessed during the 2017-2018 growing seasons in Nubaria and Cairo-Alexandria regions, Egypt. Phytopathogenic fungi were isolated from dropped fruit, and four fungicides, pyraclostrobin + boscalid, difenoconazole, carbendazim, and thiophanate methyl, were tested against the diseases in vitro and under naturally occurring infections in the field. Several phytopathogenic fungi, including Alternaria alternata, Cladosporium cladosporioides, Fusarium semitectum, and Penicillium spp., were associated with apple fruit drop. A. alternata was the most frequently isolated fungus occurring during the investigation. Pathogenicity tests confirmed that the maximum percentage of apple fruit drop was noted when petioles and fruits were inoculated with mixed fungal pathogens using branch sections with fruit. In vitro tests showed that the fungicides had a variable effect against the fungal isolates depending on the concentration used. All fungicides completely inhibited the growth of A. alternata, C. cladosporioides, and F. semitectum at $400 \mathrm{mg} \cdot \mathrm{L}^{-1}$. Under naturally occurring infections, thiophanate methyl applied at fruit set had the greatest effect $(81.68 \%)$ against PAFD, followed by difenoconazole $(73.76 \%)$, pyraclostrobin + boscalid $(70.29 \%)$, and carbendazim $(66.34 \%)$. The results indicated that PAFD may in part be a result of diseases caused by certain phytopathogenic fungi, which could be controlled using a number of fungicides applied at the beginning of fruit set.
\end{abstract}

Keywords: fruit drop; sustainable systems; fungicides; Alternaria alternata

\section{Introduction}

Apples (Malus domestica Borkh.) ranked third for worldwide fruit production, at 86.1 million tonnes and with the harvested area around 4,904,305 ha, in 2018. Egyptian apple production during 2018 was estimated to be about 704,727 tonnes and the harvested area nearly $28,085 \mathrm{ha}$, with a yield $25,092 \mathrm{~kg} \cdot \mathrm{ha}^{-1}$ [1]. Apples are susceptible to several diseases, including apple scab (Venturia inaequalis), bitter rot (Colletotrichum spp.), black rot (Botryosphaeria obtuse), powdery mildew (Oidium spp.), sooty blotch (Gloeodes pomigena), flyspeck (Schizothyrium pomi), cedar-apple rust (Gymnosporangium juniperi-virgininae), and fire blight (Erwinia amylovora) [2]. Premature fruit drop is one of the major problems for apple production, leading to substantial losses in apple yield. In Egypt, it generally appears when the fruit has reached $40-50 \%$ of their final size [3]. This problem is especially noted when fruits are left to ripen for better red color development to meet consumer expectations. In some years, losses due to premature drop can exceed $50 \%$ of the total crop yield, causing significant financial losses [4]. 
Previous studies have indicated an association of several fungi involved in moldy core and core rot of dropped, as well as fully mature, apple fruit on the trees, but Alternaria alternata is the predominant fungal pathogen responsible for moldy core and core rot of apples in different regions of the world $[5,6]$. Basically, in apples after fruit set, there is a period in which fruitlet drop occurs 5-6 weeks after full bloom due to physiological causes, and this is referred to as June drop. Symptoms of moldy core can also include premature ripening and fruit drop. This disease is caused by many different species of fungi that naturally occur in the orchard.

In apple trees, the integration of aminoethoxyvinylglycine (AVG) and naphthalene acetic acid (NAA) gave excellent premature drop control and did not reduce fruit firmness after controlled atmosphere storage [7]. In 'Golden Delicious' apples, AVG inhibited ethylene production, reduced premature drop, and delayed fruit maturation on the tree, and fruit ripening and softening during storage [8]. In the current research, we focused on premature fruit drop beginning around four weeks before the expected apple harvest date. To the best of our knowledge, there is a lack of pathological studies to determine if disease pathogens may be the causes of premature apple fruit drop (PAFD) in Egypt. Therefore, this research was designed to determine the incidence and possible causal pathogen(s) of PAFD, and to verify some means for controlling the diseases, in order to promote a sustainable system in orchards.

\section{Materials and Methods}

\subsection{Disease Survey}

This study was performed during the two growing seasons of 2017 and 2018 in the Nubaria region (Beheira Governorate) and on the Cairo-Alexandria desert road (Giza Governorate), Egypt. 'Anna' apple trees (Malus domestica Borkh.) showed natural fruit drop, and internal sections of dropped fruits showed core browning. A survey was carried out across 20 orchards at each location, four weeks before the expected harvest date. The proportion of orchards which had apple fruit drop were considered for prevalence, determined using the following formula:

$$
\text { Prevalence }(\%)=\frac{\text { Number of fields showing fruit drop }}{\text { Total number of fields visited }} \times 100
$$

Percentages of naturally infected apple trees, approximately 9-12 years old, showing fruit drop disease, were recorded in the above mentioned locations during April-May each year (Figure 1). Disease incidence (\%) was calculated using the following Equation:

$$
\text { Disease incidence }(\%)=\frac{\text { Apple trees showing fruit drop disease }}{\text { Total number of tested apple trees }} \times 100
$$

\subsection{Isolation and Identification of the Causal Agents}

Isolation experiments were carried out on different parts of the fruit, calyx end, stem or pedicel end, and internal parts collected from commercial apple orchards showing fruit drop. Samples were collected as soon as they dropped after shaking the branches. Collected samples were smaller than healthy fruit, collapsed, and showed an abnormal appearance. To ensure that dropped fruit had not picked up the diseases from the soil and ground vegetation, the samples were washed under tap water then left to dry on folds of filter paper at room temperature. Small pieces, visually observed to contain both diseased and healthy tissues, were surface sterilized by immersing in $1 \%$ sodium hypochlorite solution for two minutes, rinsed three times in sterilized distilled water, left to dry, then transferred into $9 \mathrm{~cm}$ diameter Petri dishes containing potato dextrose agar (PDA) medium and incubated at $24 \pm 1^{\circ} \mathrm{C}$ for $3-5$ days in the dark. The growing fungal colonies were purified using the hyphal tip technique $[9,10]$. Purified fungi were identified on the basis of their morphological characteristics, according to Barnett and Hunter (1986) [11]. Pure culture stocks of the isolated fungi were kept on 
PDA slants at $5{ }^{\circ} \mathrm{C}$ for further study. The frequency (\%) of each fungal species was calculated using the following Equation:

$$
\text { Frequency }(\%)=\frac{\text { Number of colonies of each fungal species }}{\text { Total number of all fungi }} \times 100
$$
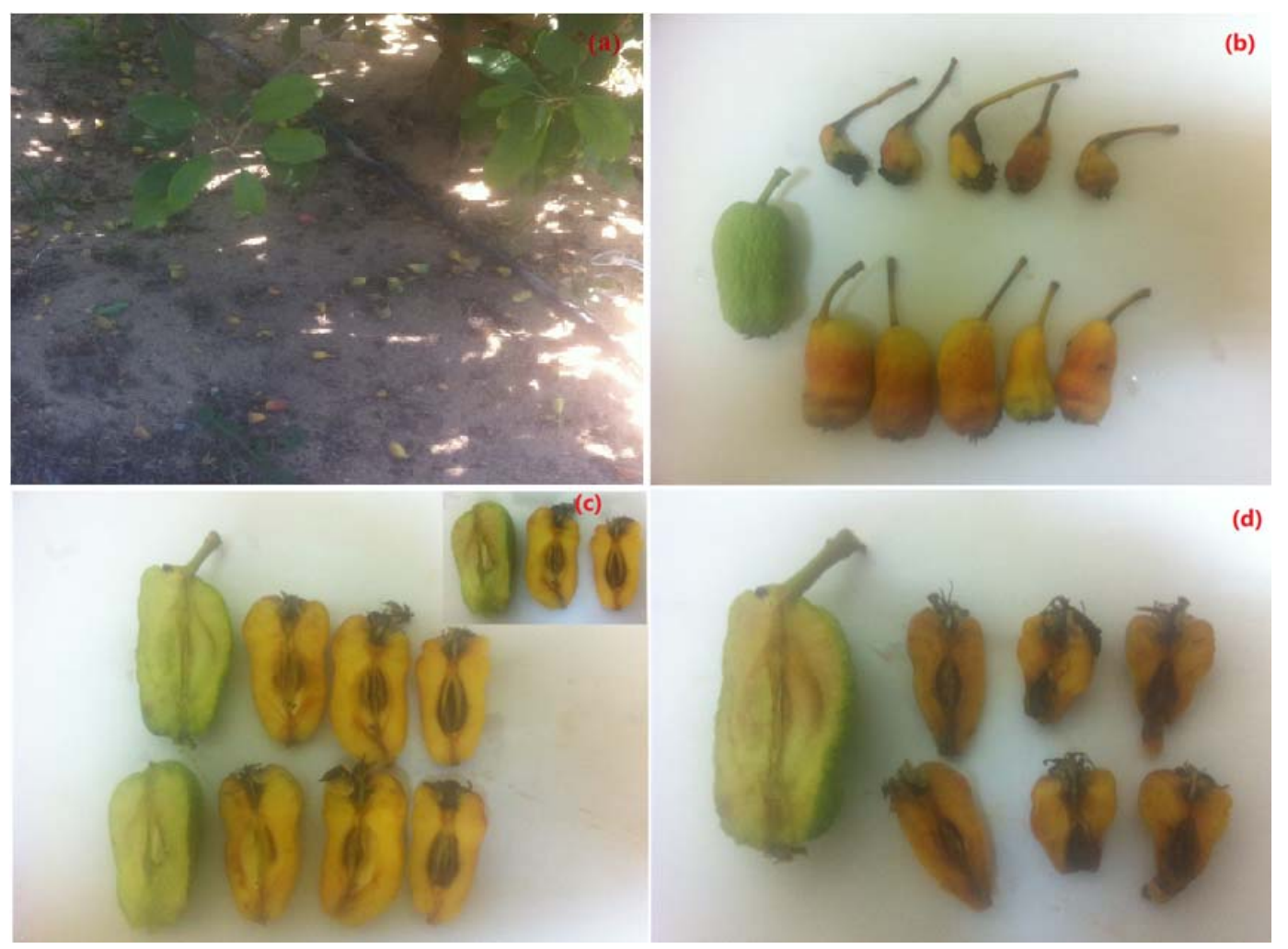

Figure 1. An 'Anna' apple tree showing natural fruit drop (a), collected dropped apple fruit (b), internal tissues of dropped apple fruit showing core browning $(\mathbf{c}, \mathbf{d})$, fruit were about half their final size.

\subsection{Pathogenicity Test}

To fulfill Koch's postulates, pathogenicity tests were conducted on healthy 'Anna' apple fruit collected at $40-50 \%$ of full size and still attached to branches and petioles, from a private apple orchard located on the Cairo-Alexandria desert road (Giza Governorate, Egypt). Apples were thoroughly washed under tap water, surface sterilized with $0.5 \%$ sodium hypochlorite solution for $2 \mathrm{~min}$, followed by washing three times in sterilized water, and then air-dried on sterilized filter paper. Finally, branches with prepared fruit were individually inserted into $1 \mathrm{~L}$ sterilized glass bottles, each containing $250 \mathrm{~mL}$ nutrient solution ( $1 \%$ urea $+2 \% \mathrm{~K}_{2} \mathrm{SO}_{4}+0.5 \% \mathrm{ZnSO}_{4}+0.3 \%$ Borax), as recommended by Khamis et al. [12].

Conidial suspensions of isolated fungi (Alternaria alternata, Cladosporium cladosporioides, Fusarium semitectum, and Penicillium spp.), individual or mixed, were prepared from seven-day-old cultures grown on PDA plates ( $9 \mathrm{~cm}$ in diameter), according to Hussien et al. [13], and adjusted to $10^{6}$ spores $\mathrm{mL}^{-1}$ following the methods of Lachhab et al. [14]. The same concentration of $10^{6}$ spores. $\mathrm{mL}^{-1}$ was used for the mixed infection. Inoculation was done according to Youssef et al. [15], by injecting either fruit petioles or fruit with $50 \mu \mathrm{L}$ of the spore suspension. A set of petioles and control fruit were injected with sterilized water only. The wounds were covered with melted $\left(54^{\circ} \mathrm{C}\right)$ wax [16]. Bottles were then incubated under laboratory conditions $\left(18-25^{\circ} \mathrm{C}\right)$ and high relative humidity for $5-7$ days. Five bottles, each containing a branch with $4-5$ attached fruit, were used as replicates for each treatment. The causal 
agents of rot were re-isolated for identity confirmation. Dropped fruit (DF) percentages were calculated using the following Equation:

$$
\text { Dropped fruit }(\%)=\frac{\text { Number of dropped fruits }}{\text { Number of fruits remaining attached to branches }} \times 100
$$

\subsection{Effect of Different Fungicides Against Causal Agents In Vitro}

Four fungicides, pyraclostrobin + boscalid $\left(\right.$ Bellis $\left.^{\circledR}\right)$, difenoconazole $\left(\right.$ Score $\left.{ }^{\circledR}\right)$, carbendazim $\left(\right.$ Kemazed $\left.{ }^{\circledR}\right)$, and thiophanate methyl (Onest ${ }^{\circledR}$ ), were evaluated in vitro for their efficacy against fungal mycelial growth. Fungal mycelia plugs (5 $\mathrm{mm}$ in diameter), from the growing edge of one-week-old cultures, were placed in the center of Petri dishes with PDA amended with the tested fungicides at final concentrations of 100, 200, and $400 \mathrm{mg} \cdot \mathrm{L}^{-1}$. PDA plates without any added fungicide served as the control. Each fungicide/concentration included three plates as replicates and the whole experiment was repeated twice. The inoculated plates were incubated at $24 \pm 1{ }^{\circ} \mathrm{C}$ and radial fungal growth was recorded after 5-7 days of incubation. Fungal growth $(\mathrm{mm})$ was calculated as the average of the orthogonal diameter $[17,18]$.

\subsection{Field Application of Different Fungicides Against Fruit Drop Disease}

Four fungicides, pyraclostrobin + boscalid $\left(\right.$ Bellis $\left.^{\circledR}\right)$, difenoconazole $\left(\right.$ Score $\left.{ }^{\circledR}\right)$, carbendazim $\left(\right.$ Kemazed $\left.{ }^{\circledR}\right)$, and thiophanate methyl (Onest $\left.{ }^{\circledR}\right)$, were evaluated in the field under natural conditions of infection at recommended doses $(30 \mathrm{~g}, 50 \mathrm{~mL}, 50 \mathrm{~g}$, and $65 \mathrm{~g}$ per $100 \mathrm{~L}$ of water, respectively) approved by the Agricultural Pesticide Committee (APC) in the Ministry of Agriculture and Land Reclamation, Egypt. Those fungicides were already registered in Egypt to control apple scab and powdery mildew. The fungicides were applied by spraying the recommended dose at the beginning of fruit set on a private farm on the Cairo-Alexandria desert road (Giza Governorate), Egypt. Set fruits were counted before the fungicide application [15]. The orchards were divided into a randomized complete block design. Five trees, each with three branches/tree, were used as replicates for each treatment. Additionally, five trees sprayed with water only were used as the control. The percentage of dropped fruits was calculated as previously mentioned. Moreover, the efficiencies of the tested fungicides were calculated according to the following formula:

$$
\text { Efficienty }(\%)=\frac{\text { Dropped fruits }(\%) \text { in the control group }- \text { Dropped fruits }(\%) \text { in the treated group }}{\text { Dropped fruits }(\%) \text { in the control group }} \times 100
$$

\subsection{Statistical Analysis}

Percentage data were arcsine-transformed before the analyses to normalize variance. Data were subjected to one-way analysis of variance (ANOVA) using Statistica Software Ver. 6.0 (Stat Soft Inc., Tulsa, OK, USA). Fisher's protected least significant difference test was used at $p \leq 0.05$ to distinguish the differences among various treatments [19].

\section{Results}

\subsection{Disease Survey}

Disease was observed in all locations. Data presented in Table 1 show that the disease incidence (\%) was higher during 2018 than 2017. The maximum disease incidence $(75.3 \%)$ was recorded in the Nubaria region followed by the Cairo-Alexandria desert road (73.5\%) in 2018, but reached $69.7 \%$ and $61.5 \%$, respectively, in 2017. 
Table 1. Disease incidence (\%) of dropped apple fruit in the investigated locations.

\begin{tabular}{lcc}
\hline \multirow{2}{*}{ Locations } & \multicolumn{2}{c}{ Disease Incidence (\%) } \\
\cline { 2 - 3 } & 2017 Season & 2018 Season \\
\hline Nubaria region (Beheira Governorate) & $69.7 \pm 1.46 \mathrm{a}^{\mathrm{z}}$ & $75.3 \pm 1.13 \mathrm{a}$ \\
Cairo-Alexandria desert road (Giza Governorate) & $61.5 \pm 1.03 \mathrm{a}$ & $73.5 \pm 1.45 \mathrm{~b}$ \\
\hline
\end{tabular}

${ }^{z}$ Means \pm standard error followed by different letters within seasons are significantly different by Fisher's protected LSD test at $p \leq 0.05$.

\subsection{Isolation and Identification of the Causal Organisms}

The frequency of fungi isolated from naturally infected apple fruit collected from two different locations is shown in Table 2. Isolation and identification revealed that four different fungi, Alternaria alternata, Cladosporium cladosporioides, Fusarium semitectum, and Penicillium spp., were associated with the naturally infected apple fruit, with average frequencies of $60 \%, 19 \%, 11 \%$, and $10 \%$, respectively. In general, A. alternata was the most prevalent fungus isolated.

Table 2. Frequency (\%) of fungal species from naturally infected 'Anna'apple fruit collected from different locations in Beheira and Giza Governorates, Egypt.

\begin{tabular}{lccc}
\hline Fungus & $\begin{array}{c}\text { Nubaria Region } \\
\text { (Beheira Governorate) }\end{array}$ & $\begin{array}{c}\text { Cairo-Alexandria Desert Road } \\
\text { (Giza Governorate) }\end{array}$ & Mean (\%) \\
\hline Alternaria alternata & $62.0 \pm 1.15 \mathrm{a}^{\mathrm{z}}$ & $58.0 \pm 2.30 \mathrm{a}$ & 60.0 \\
Cladosporium cladosporioides & $18.0 \pm 2.03 \mathrm{~b}$ & $20.0 \pm 0.88 \mathrm{~b}$ & 19.0 \\
Fusarium semitectum & $12.0 \pm 1.16 \mathrm{~b}$ & $10.0 \pm 0.58 \mathrm{~b}$ & 11.0 \\
Penicillium spp. & $8.0 \pm 0.67 \mathrm{~b}$ & $12.0 \pm 1.15 \mathrm{~b}$ & 10.0 \\
\hline
\end{tabular}

${ }^{\mathrm{z}}$ Means \pm standard error followed by different letters within the same column are statistically different according to Fisher's protected LSD test $(p \leq 0.05)$.

\subsection{Pathogenicity of the Isolated Fungi}

Koch's postulates were fulfilled by artificially infecting 'Anna'apple fruit attached to branches collected from 12-year-old trees. After seven days, tests confirmed that the pathogenicity of the fungal isolates varied between them in terms of infection rate, whereas the control treatment did not show any symptoms. Generally, the maximum percentage of dropped fruit was recorded on petioles and fruits inoculated with mixed fungal pathogens, at $78 \%$ and $62 \%$, respectively (Table 3 ). Comparing pathogens, the results showed that the percentages of dropped fruit were higher on petioles and fruits inoculated with A. alternata, followed by C. cladosporioides, and then F. semitectum. The lowest percentage of dropped fruits was observed for Penicillium spp., which was ignored for subsequent experiments.

Table 3. Pathogenicity of the isolated fungi on 'Anna' apple petioles and fruits expressed as the percentage of dropped fruits.

\begin{tabular}{lcc}
\hline \multirow{2}{*}{ Pathogen } & \multicolumn{2}{c}{ Dropped Fruits (\%) } \\
\cline { 2 - 3 } & Petioles & Fruits \\
\hline Alternaria alternata & $62.0 \pm 0.88 \mathrm{~b}^{\mathrm{z}}$ & $52.0 \pm 2.31 \mathrm{~b}$ \\
Cladosporium cladosporioides & $40.0 \pm 1.15 \mathrm{c}$ & $30.0 \pm 2.91 \mathrm{c}$ \\
Fusarium semitectum & $22.0 \pm 1.45 \mathrm{~d}$ & $18.0 \pm 1.15 \mathrm{~d}$ \\
Penicillium spp. & $8.0 \pm 1.15 \mathrm{e}$ & $6.0 \pm 1.15 \mathrm{e}$ \\
Mixed fungi & $78.0 \pm 0.88 \mathrm{a}$ & $62.0 \pm 2.30 \mathrm{a}$ \\
Control & $0.0 \pm 0.0 \mathrm{f}$ & $0.0 \pm 0.0 \mathrm{e}$ \\
\hline
\end{tabular}

${ }^{\mathrm{z}}$ Means \pm standard error followed by different letters within the same column are statistically different according to Fisher's protected LSD test $(p \leq 0.05)$. 


\subsection{Effect of Different Fungicides against Causal Agents In Vitro}

The effectiveness of four fungicides, each applied at three different concentrations, against the isolated pathogenic fungi is shown in Table 4. Generally, all fungicides completely inhibited the growth of A. alternata, C. cladosporioides, and F. semitectum at $400 \mathrm{mg} \cdot \mathrm{L}^{-1}$. Additionally, difenoconazole completely inhibited the growth of A. alternata and C. cladosporioides at $200 \mathrm{mg} \cdot \mathrm{L}^{-1}$; thiophanate methyl was able to completely inhibit the three pathogens at $200 \mathrm{mg} \cdot \mathrm{L}^{-1}$; carbendazim completely inhibited C. cladosporioides and F. semitectum at $200 \mathrm{mg} \cdot \mathrm{L}^{-11}$. None of the fungicides suppressed the pathogens at $100 \mathrm{mg} . \mathrm{L}^{-1}$.

Table 4. Effect of four fungicides at 100,200 , and $400 \mathrm{mg} \cdot \mathrm{L}^{-1}$ against isolated pathogenic fungi growth

$(\mathrm{mm})$ in vitro recovered from 'Anna' apples after premature fruit drop.

\begin{tabular}{|c|c|c|c|c|c|c|c|c|c|}
\hline \multirow{3}{*}{ Active Ingredient } & \multicolumn{9}{|c|}{ Fungal Growth $(\mathrm{mm})$} \\
\hline & \multicolumn{3}{|c|}{ A. alternata } & \multicolumn{3}{|c|}{ C. cladosporioides } & \multicolumn{3}{|c|}{ F. semitectum } \\
\hline & 100 & 200 & 400 & 100 & 200 & 400 & 100 & 200 & 400 \\
\hline $\begin{array}{l}\text { Pyraclostrobin + boscalid } \\
(38 \% \text { WG })\end{array}$ & $51.3 \pm 1.33 c^{z}$ & $26.7 \pm 0.66 c$ & $0.0 \pm 0.0 \mathrm{~b}$ & $58.7 \pm 2.40 \mathrm{~b}$ & $18.7 \pm 0.67 \mathrm{~b}$ & $0.0 \pm 0.0 \mathrm{~b}$ & $49.3 \pm 0.66 b$ & $28.7 \pm 0.67 \mathrm{~b}$ & $0.0 \pm 0.0 \mathrm{~b}$ \\
\hline Difenoconazole ( $25 \%$ EC) & $29.3 \pm 0.67 \mathrm{~d}$ & $0.0 \pm 0.0 \mathrm{~d}$ & $0.0 \pm 0.0 \mathrm{~b}$ & $20.7 \pm 0.66 \mathrm{~d}$ & $0.0 \pm 0.0 c$ & $0.0 \pm 0.0 \mathrm{~b}$ & $41.3 \pm 0.67 \mathrm{c}$ & $23.3 \pm 0.66 c$ & $0.0 \pm 0.0 \mathrm{~b}$ \\
\hline Carbendazim (50\% WP) & $58.0 \pm 2.0 \mathrm{~b}$ & $39.3 \pm 0.66 b$ & $0.0 \pm 0.0 \mathrm{~b}$ & $27.3 \pm 1.3 c$ & $0.0 \pm 0.0 c$ & $0.0 \pm 0.0 \mathrm{~b}$ & $18.7 \pm 0.66 \mathrm{~d}$ & $0.0 \pm 0.0 \mathrm{~d}$ & $0.0 \pm 0.0 \mathrm{~b}$ \\
\hline $\mathrm{H}_{2} \mathrm{O}$ & $90.0 \pm 0.0 \mathrm{a}$ & $90.0 \pm 0.0 \mathrm{a}$ & $90.0 \pm 0.0 \mathrm{a}$ & $90.0 \pm 0.0 \mathrm{a}$ & $90.0 \pm 0.0 \mathrm{a}$ & $90.0 \pm 0.0 \mathrm{a}$ & $90.0 \pm 0.0 \mathrm{a}$ & $90.0 \pm 0.0 \mathrm{a}$ & $90.0 \pm 0.0 \mathrm{a}$ \\
\hline
\end{tabular}

${ }^{\mathrm{z}}$ Means \pm standard error followed by different letters within the same column are statistically different according to

Fisher's protected LSD test $(p \leq 0.05)$.

\subsection{Field Application of Different Fungicides Against Fruit Drop Disease}

The effect of the four fungicides was evaluated for the control of apple fruit drop disease under natural field infection. Apple fruit drop percentages were $12.0 \%, 10.6 \%, 13.6 \%$, and $7.4 \%$ on trees treated with pyraclostrobin + boscalid, difenoconazole, carbendazim, and thiophanate methyl, respectively (Table 5). The thiophanate methyl fungicide was the best one and recorded an efficiency of $81.6 \%$, followed by difenoconazole, pyraclostrobin + boscalid, and carbendazim, as compared with the control group.

Table 5. Efficiency (\%) of four fungicides against apple fruit drop in 'Anna' apples under naturally occurring infection in the orchard.

\begin{tabular}{lccc}
\hline Active Ingredient & Applied Dose & Dropped Fruits (\%) & Efficiency (\%) \\
\hline Pyraclostrobin + boscalid (38\% WG) & $30 \mathrm{~g} \cdot 100 \mathrm{~L}^{-1}$ & $12.0 \pm 0.63 \mathrm{bc}$ & 70.29 \\
Difenoconazole (25\% EC) & $50 \mathrm{~mL} \cdot 100 \mathrm{~L}^{-1}$ & $10.6 \pm 0.98 \mathrm{c}$ & 73.76 \\
Carbendazim (50\% WP) & $50 \mathrm{~g} \cdot 100 \mathrm{~L}^{-1}$ & $13.6 \pm 1.32 \mathrm{~b}$ & 66.34 \\
Thiophanate methyl (70\% WP) & $65 \mathrm{~g} \cdot 100 \mathrm{~L}^{-1}$ & $7.4 \pm 0.50 \mathrm{~d}$ & 81.68 \\
Control & - & $40.4 \pm 0.75 \mathrm{a}$ & -
\end{tabular}

${ }^{\mathrm{z}}$ Means \pm standard error followed by different letters within the same column are statistically different according to Fisher's protected LSD test $(p \leq 0.05)$.

\section{Discussion}

The objectives of this research were to determine the incidence and possible causal pathogens of PAFD, and to verify the activity of some fungicides to control the disease. PAFD is becoming more common and severe in apple orchards in Egypt, and is inflicting substantial losses. This phenomenon, naturally common in fruit trees, usually occurs immediately prior to fruit ripening. A separation zone occurs either in the proximal end contact area of the pedicel ofthe fruit, or it may occur in the layer of fruit peel and skin [20]. There are several factors that can trigger early fruit drop, including overcropping, insufficient pollination, high ethylene levels, excessive summer pruning, insect damage/diseases, extremes in weather, and poor tree nutrition. 
The results of this study showed that the maximum incidence of fruit drop occurred in the Nubaria region $(75 \%)$ followed by the Cairo-Alexandria desert road (73.5\%) area in 2018. Several factors, including the suitability of regular agricultural practices, age of the orchard, types and efficiency of sanitary methods, and chemical protectant or curative treatments against diseases and insects, were likelyinvolved, which may explain the differences between the inspected locations and growing seasons. Similarly, Raja et al. [4] demonstrated that orchard and climatic factors, including mineral nutrition, summer pruning, insects and mites, water availability, and growing season temperatures, can affect premature fruit drop.

In addition to the other factors, diseases have an important role in lowering the yield of fruit trees. In this study, various phytopathogenic fungi, i.e., A. alternata, C. cladosporioides, F. semitectum, and Penicillium spp., were recovered from dropped apple fruit. A. alternata was the most frequently isolated fungus. Previously, several fungi, such as Alternaria spp., Penicillium spp., and Fusarium spp., were isolated from apple fruit. Particularly, Alternaria spp. was the most common fungus associated with diseased 'Anna' apple fruit [6]. Moreover, Gao et al. [21] found that A. alternata, A. tenuissima, A. arborescens, C. cladosporioides, and C. tenuissimum were the main pathogens causing core browning and moldy core of 'Fuji' apple fruit in China. Furthermore, A. alternata, Pleospora herbarum, Coniothyrium spp., Penicillium funiculosum, P. expansum, and P. ramulosum were associated with core rot of 'Starking Delicious' apple fruit in South Africa [22,23]. In a previous study, four phytopathogenic fungi, A. alternata, Lasiodiplodia theobromae, F. semitectum, and Pestalotia psidii, were isolated from dropped guava fruit samples collected from different orchards [15].

Pathogenicity tests confirmed that the maximum percentage of PAFD was noted on petioles and fruits inoculated with mixed fungal pathogens. In particular, the percentages of PAFD were higher when the fruit were artificially inoculated with A. alternata, followed by C. cladosporioides and F. semitectum. Racskó et al. [24] confirmed that fruit drop is often caused by damage due to diseases and pests. Additionally, a fungus causing peach brown rot (Monilinia fructicola) was recognized as initiating fruit drop. It is polyphagous, appears in many fruit species, and is responsible for immediate premature fruit drop. A significant pathogen of larger fruit (apple, pear, apricot, peach), as well as smaller fruit (sweet and sour cherry, plum), may be due to fruit on trees overwintering as shriveled mummies [25-27]. Likewise, A. alternata and F. semitectum were associated with brown apical necrosis and caused fruit drop of English walnut [28].

In vitro tests showed that four fungicides had a variable effect against the isolated fungi, depending on the concentration used. All fungicides completely inhibited the growth of A. alternata, C. cladosporioides, and F. semitectum at $400 \mathrm{mg} \cdot \mathrm{L}^{-1}$. Under naturally occurring infection, fruit set application of thiophanate methyl had the highest efficacy $(81.68 \%)$ against PAFD, followed by difenoconazole $(73.76 \%)$, pyraclostrobin + boscalid $(70.29 \%)$, and carbendazim $(66.34 \%)$. The fungicides used in this research are registered to control apple scab and powdery mildew in several countries, including Egypt, and farmers frequently use them during the season, depending on the management program in the orchard. Thus, it is easy to integrate these fungicides in the integrated pest management program of apple. We believe that the further application of those fungicides to apple trees can play a role in reducing fruit drop. Fungicide application at fruit set may work since its early application can help to reduce or prevent primary infections/inocula by the phytopathogenic fungi identified by this research. In fact, if primary infection by phytopathogenic fungi is not well controlled, secondary infection will be a problem and be more difficult to manage. Any delay incontrolling the disease is not recommended, even if adequate fungicides are used. PAFD is variable among orchards, suggesting that cultural management can influence fruit drop. Strategies to reduce PAFD can help preserve crop yield, which is an essential factor for the economic success of an orchard [29]. In this context, a previous study showed that guava fruit drop could be controlled by applying either thiophanate methyl $50 \%+$ thiram $30 \%$ or carbendazim $(50 \% \mathrm{WP})$ at aproportionof $70 \mathrm{~g} \cdot 100 \mathrm{~L}^{-1}$ water [15]. The successful control of a disease is dependent on the reliability of pathogen detection at a latent phase [30]. Raja et al. [4] summarized some effective compounds to reduce premature drop, such as naphthaleneacetic acid, 
naphthalene acetamide, propionic acid, propanoic acid, 2,4-dichlorophenoxy acetic acid, lactidichlor ethyl, and butyric acid. Additionally, other plant growth regulators have been investigated for their ability to reduce fruit drop, such as gibberellic acid $\left(\mathrm{GA}_{3}\right), 2,4$-dichlorophenoxyacetic $(2,4-\mathrm{D})$, and hydrogen peroxide [31].

Flowering and fruit set are probably the most important of allthe events occurring once an apple tree has reached reproductive maturity. Given favorable environmental conditions, the timing and intensity of flowering greatly determines when and how much fruit will be produced during the season. Prolonged flooding may lead to fruit and leaf drop, leaf chlorosis, stem dieback, and tree death. Trees are generally more tolerant of flooding during cool weather [32]. The majority of phytopathogenic fungi affecting flowers promotes and speeds up abscission [33]. In apple, the varieties exhibiting less fruit drop were 'Stayman', 'Gala', 'Melrose', 'Akane', and 'Fuji' [24]. In citrus species, fruit drop after bloom was caused by Colletotrichum acutatum and C. gloeosporioides [34]. Nature provides plants with phenolic compounds that may play an essential role in growth and resistance to pathogens, and exhibit a wide range of anti-microbial effects [35]. Racskó et al. [24] showed that fruit drop in walnuts was induced by Gnomonia spp., but the symptoms appeared only on the epicarp. In peaches, premature fruit drop caused by Venturia carpophila, the causal agent of scab, is dangerous during an extended period of drought. With a vigorous infection, fruit drop may occur in peaches when infected by Taphrina deformans, causing leaf-curl disease [24]. Finally, severe fruit drop could contribute to low yield in apple orchards and lead to great economic losses in many production areas. The role of different horticultural and climatic factors in apple fruit drop has not been fully investigated. This is the first research dealing with PAFD disease under Egyptian conditions.

\section{Conclusions}

Alternaria alternata, Cladosporium cladosporioides, Fusarium semitectum, and Penicillium spp. were associated with apple fruit drop, with $A$. alternata being the most prevalent. The maximum percentage of apple fruit drop in lab tests was observedwhen petioles and fruitswere inoculated with mixed fungal pathogens. The fungicides pyraclostrobin + boscalid, difenoconazole, carbendazim, and thiophanate methyl completely inhibited the growth of A. alternata, C. cladosporioides, and F. semitectum at $400 \mathrm{mg} \cdot \mathrm{L}^{-1}$ in in vitro tests. Under natural occurring infection, thiophanate methyl had the highest efficacy in reducing premature fruit drop, followed by difenoconazole, pyraclostrobin + boscalid, and carbendazim, when applied at the beginning of fruit set. Premature apple fruit drop is a complex phenomenon and there are various factors affecting it, such as mineral nutrition, summer pruning, insects and diseases, moisture availability, and growing season temperatures. This research indicated that PAFD may also be a result of diseases caused by certain phytopathogenic fungi, which could be controlled using a number of fungicides at the fruit set stage. We recommend that growers in arid climates might need to apply fungicides more frequently than is commonly done to overcome this problem. Finally, further studies are needed to investigate the importance of disease in premature fruit drop.

Author Contributions: K.Y. conceived the research idea. S.R.R. helped to analyze the data and write the paper. All authors have read and agreed to the published version of the manuscript.

Funding: This research received no external funding.

Conflicts of Interest: The authors declare no conflict of interest.

\section{References}

1. FAOSTAT. 2019. Available online: http://www.fao.org/faostat/en/\#data/QC (accessed on 10 March 2020).

2. Holb, I.J. Fungal Disease Management in Environmentally Friendly Apple Production-A Review. In Climate Change, Intercropping, Pest Control and Beneficial Microorganisms; Lichtfouse, E., Ed.; Springer: Dordrecht, The Netherlands, 2009; Volume 2. 
3. Meier, U. Growth Stages of Mono-and Dicotyledonous Plants, 2nd ed.; BBCH Monograph; Federal Biological Research Centre for Agriculture and Forestry: Berlin, Germany, 2001; 158 p.

4. Raja, W.H.; UnNabi, S.; Kumawat, K.L.; Sharma, O.C. Pre harvest Fruit Drop: A Severe Problem in Apple. Indian Farmer 2017, 4, 609-614.

5. Reuveni, M.; Sheglov, D.; Sheglov, N.; Ben-Arie, R.; Prusky, D. Sensivity of Red Delicious apple fruits at various phenologic stages to infection by Alternaria alternata and mouldy core control. Eur. J. Plant Pathol. 2002, 108, 421-427. [CrossRef]

6. El-Mohamedy, R.S.R.; El-Sayed, H.Z. First Record of Core Rot Disease on Apple Fruit cv. Anna 106 Local Cultivar in Egypt. Int. J. Agric. Technol. 2015, 11, 1371-1380.

7. Sazo, M.M.; Robinson, T.L. The "Split" Application Strategy for Pre-Harvest Fruit Drop Control in a Super Spindle Apple Orchard in Western NY. New York State Hort. Soc. 2013, 21, 21-24.

8. Masia, A.; Ventura, M.; Gemma, H.; Sansavini, S. Effect of some plant growth regulator treatments on apple fruit ripening. Plant Growth Reg. 1998, 25, 127-134. [CrossRef]

9. Youssef, K.; Abo Rehab, M.A.; Abd El-Ghany, K. Preliminary investigation of Verticillium wilt on mango trees (Mangifera indica L.) in Egypt. Am.-Eurasian J. Sustain. Agric. 2014, 8, 50-58.

10. Abd-Elsalam, K.A.; Youssef, K.; Almoammar, H. First morphogenetic identification of Fusarium solani isolated from orange fruit in Egypt. Phyton 2015, 84, 128-131.

11. Barnett, H.L.; Hunter, B.B. Illustrated Genera of Imperfect Fungi, 4th ed.; Macmillan Publ. Co.: New York, NY, USA, 1986; 218 p.

12. Khamis, M.A.; Bakry, K.A.; Abd El-Moty, S.A. Improving growth and productivity of guava trees. Minia J. Agric. Res. Dev. 2007, 27, 51-70.

13. Hussien, A.; Ahmed, Y.; Al-Essawy, A.; Youssef, K. Evaluation of different salt-amended electrolysed water to control postharvest moulds of citrus. Trop. Plant Pathol. 2018, 43, 10-20. [CrossRef]

14. Lachhab, N.; Sanzani, S.M.; Fallanaj, F.; Youssef, K.; Nigro, F.; Boselli, M.; Ippolito, A. Protein hydrolysates as resistance inducers for controlling green mould of citrus fruit. Acta Hort. 2015, 1065, 1593-1598. [CrossRef]

15. Youssef, K.; Mustafa, Z.M.M.; Mounir, G.A.; Abo Rehab, M.E.A. Preliminary Studies on Fungal Species Associated with Guava Fruit Drop Disease and Possible Management. Egypt. J. Phytopathol. 2015, 43, 11-23.

16. Deverall, B.J. Biochemical changes in infection droplets containing spores of Botrytis spp. incubated in the seed cavities of pods of bean (Vicia faba L.). Ann. Appl. Biol. 1967, 59, 375-387. [CrossRef]

17. Youssef, K.; Hashim, A.F.; Margarita, R.; Alghuthaymi, M.A.; Abd-Elsalam, K.A. Fungicidal efficacy of chemically-produced copper nanoparticles against Penicillium digitatum and Fusarium solani on citrus fruit. Philipp. Agric. Sci. 2017, 100, 69-78.

18. Hashim, A.F.; Youssef, K.; Abd-Elsalam, K.A. Ecofriendly nanomaterials for controlling gray mold of table grapes and maintaining postharvest quality. Eur. J. Plant Pathol. 2019, 154, 377-388. [CrossRef]

19. Youssef, K.; de Oliveira, A.G.; Tischer, C.A.; Hussain, I.; Roberto, S.R. Synergistic effect of a novel chitosan/silica nanocomposites-based formulation against gray mold of table grapes and its possible mode of action. Int. J. Biol. Macrom. 2019, 141, 247-258. [CrossRef]

20. Arseneault, M.H.; Cline, J.A. A review of apple preharvest fruit drop and practices for horticultural management. Sci. Hortic. 2016, 211, 40-52. [CrossRef]

21. Gao, L.L.; Zhang, Q.; Sun, X.Y.; Jiang, L.; Zhang, R.; Sun, G.Y.; Zha, Y.L.; Biggs, A.R. Etiology of moldy core, core browning, and core rot of Fuji apple in China. Plant Dis. 2013, 97, 510-516. [CrossRef]

22. Combrink, J.C.; Kotzl, J.M.; Wehner, F.C.; Grobbelaar, C.J. Fungi associated with core rot of Starking apples in South Africa. Phytophylactica 1985, 17, 81-83.

23. Combrink, J.C.; Visagie, T.R.; Grobbelaar, C. Variation in the incidence and occurrence in different production areas of core rot in Starking apples. Deciduous Fruit Grow. 1984, 34, 88-89.

24. Racskó, J.; Leite, G.B.; Petri, J.L.; Zhongfu, S.; Wang, Y.; Szabó, Z.; Soltész, M.; Nyéki, J. Fruit drop: The role of inner agents and environmental factors in the drop of flowers and fruits. Int. J. Hort. Sci. 2007, 13, 13-23. [CrossRef]

25. Holb, I.J. The brown rot fungi of fruit crops (Monilinia spp.) I. Important features of their biology (Review). Int. J. Hortic. Sci. 2003, 9, 23-36. [CrossRef]

26. Holb, I.J. The brown rot fungi of fruit crops (Monilinia spp.) II. Important features of their epidemiology (Review). Int. J. Hortic. Sci. 2004, 10, 17-33. [CrossRef] 
27. Holb, I.J. The brown rot fungi of fruit crops (Monilinia spp.) III. Important features of their disease management (Review). Int. J. Hortic. Sci. 2004, 10, 31-48. [CrossRef]

28. Belisario, A.; Santori, A.; Potente, G.; Fiorin, A.; Saphy, B.; Reigne, J.L.; Pezzini, C.; Bortolin, E.; Valier, A. Brown Apical Necrosis (BAN): A Fungal Disease Causing Fruit Drop of English Walnut. Acta Hort. 2010, 861, 449-452. [CrossRef]

29. Bravin, E.; Kilchenmann, A.; Leumann, M. Six hypotheses for profitable apple production based on the economic work-package within the ISAFRUIT Project. J. Hortic. Sci. Biotechnol. 2009, 84, 164-167. [CrossRef]

30. Alghuthaymi, M.A.; Ali, A.A.; Hashim, A.F.; Abd-Elsalam, A. A rapid method for the detection of Ralstonia solanacerum by isolation DNA from infested potato tubers based on magnetic nanotools. Philipp. Agric. Sci. 2016, 99, 113-118.

31. Khandaker, M.M.; Idris, N.S.; Ismail, S.Z.; Majrashi, A.; Alebedi, A.; Mat, N. Causes and Prevention of Fruit Drop of Syzygium samarangense (Wax Apple): A Review. Adv. Environ. Biol. 2016, 10, 112-123.

32. Crane, J.H.; Balerdi, C.F. Guava Growing in the Florida Home Landscape. Available online: https: //edis.ifas.ufl.edu/pdffiles/MG/MG04500.pdf (accessed on 25 May 2020).

33. Singh, Z.; Malik, A.U.; Davenport, T.L. Fruit drop in mango. Hort. Rev. 2005, 31, 111-153.

34. Marques, J.P.R.; Amorim, L.; Spósito, M.B.; Appezzato-da-Glória, B. Histopathology of postbloom fruit drop caused by Colletotrichum acutatum in citrus flowers. Eur. J. Plant Pathol. 2013, 135, 783-790. [CrossRef]

35. Taha, F.S.; Wagdy, S.M.; Hassanein, M.M.M.; Hamed, S.F. Evaluation of the biological activity of sunflower hull extracts. Grasas y Aceites 2012, 63, 184-193.

(C) 2020 by the authors. Licensee MDPI, Basel, Switzerland. This article is an open access article distributed under the terms and conditions of the Creative Commons Attribution (CC BY) license (http://creativecommons.org/licenses/by/4.0/). 